\title{
Peripheral T-cell Lymphoma Prognostic Index Score 3-4
}

National Cancer Institute

\section{Source}

National Cancer Institute. Peripheral T-cell Lymphoma Prognostic Index Score 3-4. NCI

Thesaurus. Code C161795.

A risk group associated with a total score of 3 or 4 on the Prognostic Index for Peripheral

T-cell Lymphoma indicating that an individual has a high risk. 